\title{
Seeking Justice through Interdisciplinary Environmental Education at Postgraduate Level: Lessons from Melbourne, Australia
}

\author{
En Busca de la Justicia a través de la Educación Ambiental \\ Interdisciplinaria en Posgrado: Lecciones desde Melbourne, \\ Australia
}

\author{
Simon P. J. Batterbury ${ }^{12} *$ \\ Maurizio Toscano ${ }^{2}$ \\ ${ }^{1}$ Lancaster Environment Centre, Reino Unido \\ ${ }^{2}$ University of Melbourne, Australia
}

\begin{abstract}
Masters degrees that offer a broad understanding of environmental issues have been taught in universities since the 1960s. As the problems, they address have increased in severity and become global in scale and reach, higher education offerings have flourished accordingly. Today, environmental Masters degrees offer a variety of specializations, are often embedded within university environmental institutes or centers, and they lead thousands of students into environmental careers, as activists, advocates, policymakers, technicians, resource managers, and researchers. They provide an opportunity to understand and critically debate mainstream concepts, like sustainability, the green economy, ecological resilience, environmental services, and good governance. The severity of environmental crises also requires a more radical curriculum: critiques of economic growth (including green growth), social and environmental justice, and the political ecology of unequal access to resources. In light of these complex demands and growing opportunities for environmental programs to address social and environmental justice, we discuss a unique and successful model for interdisciplinary environmental Masters teaching at a large Australian university that has juggled promotion of justice in its program along with meeting financial targets imposed by the neoliberal regime prevalent in Australia's underfunded higher education sector. The program has a distinctive approach to interdisciplinary learning, permitting a very wide range of student choice, and unified teaching efforts across ten Faculties. This has required agile administration, and strong defense of an unusual approach to the management of environmental pedagogy. The Master of Environment program illustrates how taught postgraduate programs can offer an alternative space for personal, institutional and environmental commitment to social and environmental justice.
\end{abstract}

Keywords: Training; Australia; Environmental education; Social justice; Higher education.

Los Máster que abordan los problemas ambientales han sido impartidos en las universidades desde la década de 1960. A medida que ha aumentado la severidad de los problemas que abordan y se han vuelto globales en escala y alcance, las ofertas de educación superior han aumentado también en consecuencia. Hoy en día, los Máster ambientales ofrecen una variedad de especializaciones, a menudo integrados en institutos o centros ambientales de la universidad, y conducen a miles de estudiantes de carreras ambientales, como activistas, defensores, formuladores de políticas, técnicos, administradores de recursos e investigadores. Brindan una

*Contacto: simonpjb@unimelb.edu.au

Recibido:

30 de octubre 2017

ISSN: 2254-3139

$1^{\text {a }}$ Evaluación: 15 de diciembre 2017

www.rinace.net/riejs/

$2^{\text {a }}$ Evaluación: 22 de marzo 2018

revistas.uam.es/riejs

Aceptado: $\quad 3$ de abril 2018 
oportunidad para comprender y debatir críticamente principales conceptos como la sostenibilidad, la economía verde, la resiliencia ecológica, los servicios ambientales y la buena gobernanza. La gravedad de las crisis ambientales también requiere un currículum más radical: críticas sobre el crecimiento económico (incluido el crecimiento ecológico), justicia social y ambiental, y sobre la ecología política que aborda el acceso desigual a los recursos. A la luz de estas complejas demandas y de las crecientes oportunidades de formación para abordar la justicia social y ambiental, discutimos un modelo único y exitoso de Máster ambiental interdisciplinar que se imparte en una gran universidad australiana que ha hecho promovido la justicia en su programa aun cuando se realiza en un contexto marcado por objetivos financieros impuestos por el régimen neoliberal prevalente en el sector de educación superior en Australia, y con financiación insuficiente. El programa tiene un enfoque distintivo para el aprendizaje interdisciplinario, lo que permite una amplia gama de opciones para los estudiantes, y para la enseñanza en diez facultades. Esto ha requerido una administración ágil y una fuerte defensa de un enfoque inusual para la gestión de la pedagogía ambiental. El programa de Maestría en Medio Ambiente ilustra cómo los programas de posgrado pueden ofrecer un espacio alternativo para el compromiso personal, institucional y ambiental con la justicia social y ambiental.

Descriptores: Enseñanza; Australia; Educación ambiental; Justicia social; Enseñanza superior.

\section{Introduction}

The teaching of interdisciplinary university environmental courses at universities, frequently termed environmental studies, dates back to the 1960s and 1970s (Hanover Research Council, 2009; Kull and Batterbury, 2017; Palmer, 2002). The first concerted postwar efforts at regulation of the serious environmental concerns revealed by scientists in those decades generated a flurry of interest and concern (Monroe, Andrews and Biedenweg, 2008). A sometimes-militant environmental movement grew alongside more general awareness in western countries, challenging the consequences of postwar economic growth and deleterious environmental behaviors. The momentum that was generated by the radical actions of the 1960s seeking social change and environmental justice was not to last -at least not in this form. However, one result was that some universities and colleges established interdisciplinary environmental studies programs at undergraduate level, particularly in the liberal arts colleges in the United States (Emmelin, 1977; Kull and Batterbury, 2017). These programs drew on and expanded upon individual classes in ecology, demography, engineering and other domains that had already been taught for decades. These were supported by some international guidelines like the 1977 United Nations Tbilisi Declaration on Environmental Education ${ }^{1}$ and the Talloires Declaration of 1990, a pedagogical commitment by university leaders ${ }^{2}$ (Soule and Press, 1998).

Today universities offer hundreds of environmental degrees at undergraduate and postgraduate level, focused on meeting sustainability challenges in developed and developing societies, the science of the environment, different aspects of eco-innovation and corporate sustainability, environmental policymaking and law, planning and design, eco-efficient technology, environmental education, and resource conservation and management (Filho et al., 2017). Yet the mechanisms by which environmental and

\footnotetext{
${ }^{1}$ http://www.gdrc.org/uem/ee/tbilisi.html

${ }^{2}$ http://ulsf.org/talloires-declaration
} 
sustainability-focused education is delivered in higher education contexts has not received much scholarly attention, particularly where arguments for running such degrees have to be made and university budget considerations addressed. A much more common focus in the literature is the philosophy guiding environmental education, and its content (Dlouhá and Dlouhý, 2014; Jickling and Sterling, 2017; Kopnina, 2012). It is vital to learn from more successful cases where environmental education, and embedding sustainability in teaching, has actually been achieved (Adams, Martin y Boom, 2018).

In this article, we do so by focusing exclusively on the practical delivery of an environmental education program. We look at the challenges and the successes of a truly interdisciplinary environmental Master's degree, and how it has negotiated its existence in a university that requires income from its students to operate. The Master of Environment program at the University of Melbourne, Australia has maintained socially just environmental education in the face of pressures, and it has produced hundreds of graduates over the last 15 years that are now working successfully in environmental, and other occupations. We examine the mechanisms that have ensured these outcomes, as a contribution to practical understanding of environmental education strategies and options. We will conclude with some thoughts on the tractability and applicability of the Master of Environment model.

Our assessment of this program comes from direct participation in its daily management and delivery, and from a more distant appreciation of it while working elsewhere. The first author was Director of the entity that delivers the Master of Environment, the Office of Environmental Programs (OEP) from 2008-2012. Data from weekly program meetings, statistics, financial data and numerous meetings across the university were a source of information. However, because these are confidential to the program, they may only be reported in general terms and without attribution. The first and second authors have also taught OEP students and supervised their Masters projects for over a decade, learning from them, and both have served on the OEP's Academic Advisory Committee for several years. We have also headed two Masters streams. Our comparative experience elsewhere includes teaching on the Environmental Change and Management Masters at Oxford, the Environment and Development Masters at the LSE and Lancaster, education programs at Melbourne, and Geography programs at the University of Arizona, Brunel University and Roskilde University.

\section{The emergence of interdisciplinary environmental teaching}

Lying behind the demand for environmental education in recent decades is, of course, the global concern about major environmental challenges, most notably climate change, and their actual and potential impacts on environments and society. Tackling climate change requires multidisciplinary understanding, from atmospheric science to policy studies, and from environmental management through to communications, journalism, and the arts (Wilson, 2012). Meanwhile the corporate world has engaged with carbon taxation and greening its operations, out of choice or out of necessity in the emerging green economy, which requires design and engineering skills (Shmelev, 2017). Perhaps less well supported, but of great concern to social scientists, is teaching about natural hazards (whether generated by climate change or not), vulnerability to these hazards, and 
appropriate responses to current and future disasters and other forms of risk. Resource conservation issues are a further area of student interest and investment in university programs. Biodiversity conservation and the fate of wildlife and habitats occupy many academics in Departments of Biology and Zoology around the world, and attract strong interest from students interested in careers in these areas (Fien, Scott and Tilbury, 2001).

In sum, the numbers of undergraduates and postgraduates wishing to direct themselves to an environmental career is showing no sign of diminishing, at least in Europe, North America and Australasia. These regions receive strong numbers of applicant for Masters level courses in environmental topics from other parts of the world, some of which (as in Colombia, Mexico, South Africa, India, and now China) are rapidly developing their own study programs as well.

The supply of environmental education takes several forms. It is now common among research universities to have an environmental institute of some form that directs research and teaching in that area. In some cases, high-level decisions have created these entities. These include the School of Sustainability at Arizona State University, the Centre for Environmental Technology at Imperial College London, the expanded Institute of Environment at the University of Arizona, and Lancaster University's Environment Centre. The University of Arizona set up a Masters in Environmental Management in 2011, following similar moves by the universities of Princeton, Berkeley, Yale, and Michigan. The University of Oxford developed its flagship Environmental Change and Management degree over twenty years ago, embedded within the Environmental Change Institute, which was established in the 1990s. This Masters has fewer than forty places, good scholarships, and competition for entry is very strong. East Anglia in the UK started its School of Environmental Sciences, essentially a Faculty, in 1967 and under Tim O'Riordan and other staff it has taught thousands of undergraduate and Masters level students. The University of Leeds created a Sustainability Institute in 2004, offering a suite of new degrees. In Australia, Griffith University, established in 1971, had an environmental mission from the outset and has continued to teach in this area from its School of Environment, which today offers a Master of Environment with five areas of specialization.

To return to our earlier point, creating environmental courses to respond to student demand serves two ends. Training students to understand and potentially solve environmental problems is a vital and socially just motive. New environmental courses also permit universities to hire staff in these areas, to develop additional expertise, to raise their external profile, and to enter areas of research and teaching that are environmentally just. But secondly, in most cases universities only do so if these courses are identified, usually by market testing, as financially viable and self-sustaining. Revenue capture has to be a major consideration. ${ }^{3}$ Substantial centralized government subsidies or other endowments are needed to avoid charging students (Batterbury and Byrne, 2017). In Australia at least, teaching has become more lucrative than research, since it provides recurrent rather than grant-dependent income. Successful postgraduate programs aid the response to these market forces.

${ }^{3}$ Of course, the students in these courses may in time, as is customary in North America, turn into benefactors or political/economic supporters of the university later in their lives. 


\section{The university context for teaching at Melbourne}

Like the higher education system in several other Anglophone countries, Australia has a small number of elite, research-based universities, established in the $19^{\text {th }}$ century and modeled on the universities of Oxford and Cambridge, together with many others established in the two post-war decades. The University of Melbourne is an Australian research-focused university founded in the mid 1800s, with over 40,000 students and close to 7,000 staff. It is usually ranked number one in Australia and in the global top forty universities on the basis of its research performance (Times Higher Education, 2017). It has an inner-city location, and the metropolis surrounding it is a very popular destination for Australian and international students, the latter constituting about 30\% of the total student population.

Until a radical reform of its curriculum in 2008 that shifted its teaching towards an American model, the University of Melbourne operated as a quite traditional university. Governance rests largely with an executive team, led by the Vice Chancellor and the Provost and directing strategic initiatives and decision-making. Faculties have existed for over a century, but in the 2000s, the university devolved many executive functions to them, and instituted new financial accounting mechanisms. Its ten Faculties, led by Deans, now have responsibility for meeting income targets and balancing their budgets. This devolution of powers accords with new public management ideas, seeking efficiency and savings in response to declining government funding to Australian universities since the 1990 s (Batterbury and Byrne, 2017). Faculties have to show excellence on a range of indicators, and budgets and finance have become linked to agreed university targets and annual business plans, although some cross-subsidisation does occur to assist those Faculties that are less likely to attract international students or large overhead payments from research grants and contracts. Some insist their constituent parts (Departments and even individual staff) also meet fiscal and academic targets for income, student enrolments and research performance.

This decentralized and incentive-based system of public university management is common in Australia. With no academic tenure, and only permanent or fixed-term contracts, even full professors and staff with permanent contracts could be redeployed or made redundant if there are budget shortfalls (Batterbury, 2008). This certainly keeps everyone vigilant and concerned about their individual and Departmental income and performance. The need to raise revenue from fees and other sources has been resisted by advocates of the government-funded true public university, but unsuccessfully (Batterbury and Byrne, 2017; Biggs and Davis, 2002). In this competitive environment, each Faculty and academic Department has to secure enough revenue from teaching to help pay for their staffing and fixed overheads, which in real terms means encouraging students into their classes, while trying to offer fewer elective classes to their own students if this means the revenues leak to other Faculties or Departments. Without sufficient teaching income, an academic unit's survival could be at stake, and any expansion of its activities would certainly be impossible. Closure is a real possibility, although rarely enacted.

The key implication for environmental education is that, as in other universities, the result of pushing decision-making and financial probity downward has been the establishment of some degree of competition between Faculties for student numbers. Faculties and Departments compete with each other (and with other universities), to maximize their 
share of revenue flowing from students, although there are some centralized controls on this. Any initiatives that involve several Melbourne Faculties become harder to manage and to organize in such a devolved system, because their costs and incomes have to be tallied and allocated ${ }^{4}$.

Six undergraduate Bachelor degrees were introduced in 2008 under the Melbourne Model, replacing close to 100 specialist undergraduate courses once managed by the Faculties. Undergraduates must include at least four of their subjects (classes) from outside their primary discipline, introducing unprecedented competition between Faculties for student enrolments. This change produced a proliferation of classes designed to thrive in this new market, and also a boom in enrollments in some areas, like languages, that were once only available to students in those degrees. The Model led to interdisciplinary breadth classes that were developed and promoted as addressing big issues including climate change, food security, global health, human rights and global justice. With some of the six degrees now attaining total enrolments in excess of 9,000 students, each entity offering teaching must be recompensed according to its contribution. Individual classes and whole degrees, like the Bachelor of Science and Bachelor of Arts, have to determine the allocation of income from student fees to individual academic units, based on who taught what. Nonetheless, there are no central policies or guidelines in place at the time of writing to manage the distribution of income and costs associated with them, leaving this up to negotiation between Faculties.

In this environment -as in many universities around the world that are reliant on student fees- one additional area where growth in teaching can be captured is through taught Masters degrees. There are few government controls on Masters student numbers and it is financially astute for an academic unit to run or contribute to good quality Masters level teaching. This is after all, part of a neoliberal market-facing approach, as well as offering useful and inspiring courses to students. At Melbourne, Masters teaching attracted a high per-student return to Departments for many years, although this was eventually placed at parity with undergraduate enrolments following a change in policy.

\section{The master of environment}

\subsection{Program history}

The University of Melbourne was not part of the 1960s and 1970s growth in new environmental programs described above, during this period it only offered individual classes on environmental topics. Later it did not develop a single environmental institute like some other universities, but instead operates two. Firstly, the Master of Environment degree is taught from the Office for Environmental Programs. ${ }^{5}$ The OEP, unlike every other teaching unit on campus, spans all ten Faculties, even though it is embedded in a single Faculty for administrative purposes (currently, Science). Secondly, the Melbourne

\footnotetext{
4. The ownership of an interdisciplinary Masters fields like Development Studies or Planning, for example, have been a source of conflict in the past, since academics and groups contributing disciplinary expertise now reside in different Faculties, but the degrees are administered by only one.

${ }^{5}$ www.environment.unimelb.edu.au
} 
Sustainable Society Institute (MSSI) ${ }^{6}$ was established much later as one of several crossuniversity research-only institutes, without involvement in teaching.

The Master of Environment program is unique because it shares teaching duties, and revenues, across university Faculties and Departments depending on the relative contributions that each make towards teaching into the program. Establishing and building the credibility of an interdisciplinary environmental teaching program in this way has occurred in the context of a university that is committed to increasing its proportion of research degrees and taught Masters programs. But our observation is that, viewed from inside the organization, competition for students amongst different levels and academic units is notable.

By the 1990s the University had a Master of Environmental Science and a Master of Environmental Studies that were based in different Faculties, plus a few other specialist environmental offerings. One week in 1999, these two Environmental degrees (Science, and Studies) led by different groups were advertised separately side-by-side in a national daily newspaper and this potential overlap and source of confusion was brought fortuitously to the attention of Senior Management by a geographer, Brian Finlayson. In response, Mark Burgman, a professor of botany and an environmental risk specialist with green credentials, developed a way to create more coherence amongst university environmental offerings. That year, the Office for Environmental Programs was established and headed by Burgman. The OEP was charged with coordinating a new postgraduate Masters and the two existing ones were cancelled. The idea was to establish a single Master of Environment, drawing on Faculty expertise from the whole university, as well as to coordinate environmental activities across campus. The initiative was eventually housed within the non-disciplinary School of Graduate Studies before the university moved to the present, highly-devolved structure of Faculties.

It took almost three years to develop the Master of Environment with 2002 being its first intake year. Prior to that, two years were spent negotiating with Deans to develop a viable financial and governance model, discussing options and alternatives for study concentrations with individual environmentally-focused academics, conducting market research, and developing the business plan and administrative systems. The Master of Environment structure included a single core class with others drawn from a long list of existing postgraduate offerings across campus, that could be chosen as electives. The program developers anticipated that students would come from a very broad array of backgrounds and have an equally broad array of career goals. The philosophy of the OEP became guiding students to make choices that would provide them with the training and skills required to implement environmentally sustainable practices across their choice of professional domains. Students, therefore, could shop for classes to fill out their tailored program of classes over one or two years (depending on their pre-existing qualifications). They were guided by expert advice from academic staff members to assist them with navigating the options available and also to insure some coherence to the degree they were developing.

The idea of lifting most constraints on what classes students can take to get a Masterslevel coursework qualification is actually more radical than it sounds, and it has become a

${ }^{6}$ www.sustainable.unimelb.edu.au 
guiding principle of this degree. Offering cross-Faculty education distinguished the OEP from many of its competitors. Even today, virtually no other university operates in this way, although several come close (University of Chile, for example). Presently, a typical OEP student takes core classes taught by dedicated OEP lecturers, Sustainability Governance and Leadership, and Interdisciplinarity and Environment. The content has altered over the years, but they offer a survey of environmental skills and foundational ideas, and the accompanying skillset, necessary to become an environmental citizen. They also develop relationships among the student cohort. Students then choose from over 260 class offerings from 10 Faculties, with the list of choices constantly updated by the OEP team.

The Master's program began with some central university subsidies. Initial enrolments in this bold experiment were small and the fees were set quite high, but ambitions were great. In the early years, various financial models were tried to insure buy-in from the individual Faculties and to encourage broad student enrolments. Enrolments in the Master of Environment rose from 35 in 2003 to just above or below 400 students enrolled at any one time today (in 2015: 407). Prior environmental work experience can lower the length of the course below two years, or down to one year. The broadest option is still a tailored degree, but a percentage of students also choose to narrow their choices to one of 11 recognised streams; or tailored pathways that appears on their final degree transcript (Figure 1). Students enrolled in a stream also complete between 1 and 4 compulsory stream classes and complete their program by choosing from a list of stream electives and/or negotiated electives.

\begin{tabular}{l}
\hline \multicolumn{1}{c}{ OEP STREAM } \\
\hline Climate Change \\
Conservation and Restoration \\
Development \\
Education and Social Change \\
Energy Efficiency Modelling and Implementation \\
Environment and Public Health \\
Environmental Science \\
Governance Policy and Markets \\
Integrated Water Catchment Management \\
Sustainable Cities, Sustainable Regions \\
Waste Management \\
Tailored Specialisation, not within one of the above \\
\hline
\end{tabular}

Figure 1. Showing specialised streams 2017 Source: OEP.

\subsection{Program attributes}

The expected student outcomes have strengthened over the years. Professional practice attributes are expected, along with gaining skills including an Ability to envision environmental change and propose pathways to realise this change. In reality the knowledge that students gain can and does apply to advocacy, activism, research, and professional and commercial practice.

Several years ago, a capstone experience became mandatory for students approaching the end of their Master's program. The idea of the capstone is to give students the opportunity to consolidate the knowledge and skills they have engaged with over the course of the degree, and also to express this in practical application either inside or outside their core 
disciplinary area. One option for students is through completing a research project supervised by an academic staff member. The scale of these research projects varies according to the needs of students and type of project. Long research projects often run for the whole of the final year of studies, are one quarter of the degree with a 50-point (4 class equivalent) credit, and require students to submit a research thesis of 20,000 words that is presented (at a preliminary and final stage) at a cross-disciplinary conference run by the OEP, and independently examined. Less ambitious, shorter projects may be undertaken but still require students to present their work at the twice-annual conference. Around 300 have now been completed and some have been published in revised form (e.g. Noy et al., 2017 $)^{7}$. Students must begin with a research proposal that stipulates and justifies their proposed research questions and methodological approach. Project supervisors are drawn from across all the Faculties of the university and matched to the areas of expertise identified in the proposals. Once again, the fee income and project expenditure are passed from the OEP to each participating Faculty with few overhead costs held back; thus, incentivising supervision work that, because of its small scale compared to research higher degrees (PhDs), might not otherwise be seen as financially viable. Moreover, research projects can also be undertaken with an outside partner and with supervision of research drawn from researchers in that organisation. Domestic or international internships, for example in Australian environmental consultancy firms or United Nations organisations, may also be counted towards the capstone, and are guided by legal documentation and agreed assessments.

One of the great strengths of the OEP is the exchange that takes place across the academic, commercial and other institutional contexts. These opportunities for academic and nonacademic professional involvement give students access to a pool of expertise, experiences and collaborations that would otherwise be unavailable with a course structure of hard disciplinary boundaries reinforced by internal university competition. A student is able in principle to specialise their Masters in one broad discipline area (stream), undertake an internship within a different professional context and also complete research work in another. Although not many students choose to do all three, the options are in place to stretch student's skill base into organisations. This is a flexibility of practice that is increasingly necessary to encourage an equitable approach to addressing environmental and sustainability problems (Winter and Cotton, 2012).

Students who complete the Master of Environment will have:

- Knowledge to undertake professional practice in environment or sustainability, including:

$\checkmark$ Specialised knowledge in an environmental discipline or field of practice, including knowledge of recent developments in this field.

$\checkmark$ Knowledge of the cross-disciplinary nature of environmental issues and professional practice to promote sustainable futures.

$\checkmark$ Knowledge of research principles and methods applicable to specialist field of environmental inquiry.

${ }^{7}$ See the OEP Collection at https://minerva-access.unimelb.edu.au/handle/11343/42179 
- Skills for collaborative and creative problem solving in environmental practice, including:

$\checkmark$ Ability to critically analyse and synthesise environmental knowledge.

$\checkmark$ Ability to envision environmental change and propose pathways to realise this change.

$\checkmark$ Ability to communicate complex environmental knowledge and research effectively to a range of audiences.

$\checkmark$ Ability to work effectively in cross-disciplinary teams.

$\checkmark$ Technical skills for professional practice and research in field of specialisation.

- Demonstrated capacity to:

$\checkmark$ Exercise well developed judgement, adaptability and responsibility as a practitioner in an environmental discipline or professional field.

$\checkmark$ Plan and execute a substantial project in an area of environmental research or practice.

Eight Directors of the OEP (including the first author) have now held the role, most taking a secondment from elsewhere on campus, and the Office now employs two full time lecturers, several part-time tutors and lecturers, and several administrative staff. Individual course advice is still offered to all students. Governance includes an Academic Advisory Committee (AAC) attended by representative from the Faculties, while a Community and Industry Advisory Board composed of environmental employers and policy experts provides oversight of the degree's relevance to outside commercial and professional interests. In keeping with its role, a model for environmental action, advocacy and justice, the OEP is housed in a building refurbished to an environmental 5-star rating.

The OEP focuses only on education. Of course, there is always more to do across the university to develop a wider sustainability culture (Adams, Martin y Boom, 2018), as critics have clearly identified (Baer and Gallois, 2018). Elsewhere on campus, a Sustainability Charter was developed in 2016, followed by Plans with annual reporting (University of Melbourne, 2016, 2017). There have been substantial efforts to reduce campus carbon emissions and improve the built environment. The OEP has contributed to the Learning and Teaching elements of the university's Strategy/Plan and to sustainability leadership more generally. For example, it maps its program against the National Teaching and Learning Academic Standards Statement for Environment and Sustainability.

\subsection{Student diversity}

OEP students are usually disciplinarians when they complete their undergraduate study (As in Europe, but more so than in the US), so a flexible Masters with many options is something unusual, potentially broadening their skills substantially, working across disciplines and domains of expertise. Over the last fifteen years, we have observed three ideal types of students. The first group, in mid-career, are converters, they are seeking a career change to environmental work. Some come from other countries and they generally have the money for a year or two spent at an Australian university, and they see this major investment in further study to be worthwhile. The second cohort comprise those already in an environmental career or vocation, but seeking validation of their status and expertise 
through gaining a postgraduate environmental qualification. These include many international students, some taking a degree offered in the English language for the first time and arriving with international scholarships (for example, students from China, Indonesia, Vietnam, Chile, and Mexico). A third group progress straight into the Masters from an undergraduate degree at the University of Melbourne or elsewhere, and their target career options are left more open until they have progressed part-way through their degree.

Within these three groups, students are very diverse in terms of their access to funding, their socio-cultural backgrounds, professional experience and their aspirations. A concern for tackling environmental problems, often described in terms of environmental or social justice (or both), generally unites them and gender representation in the current cohort is equally balanced. Some are subsidised by the OEP through a complex process that involves government-supported places and some endowment monies. The student body is about 35\% international, with a large intake from China and Latin America at present. In exit surveys, many describe the flexibility provided by the OEP as unusual for a university, the level of pastoral care to be high, and the opportunities presented for learning and for career pathways to be exceptional. The career outcomes of several hundred graduates are diverse, and alumni are involved in everything from corporate sustainability to social and environmental activism ${ }^{8}$.

\subsection{Internal delivery mechanisms}

The OEP fosters financial and pedagogical benefits from a carefully worked-out cooperative model of program delivery, overcoming the tendency for intra-university competition elaborated above. In the OEP financial model, it is actually beneficial for academics to offer classes appealing to its interdisciplinary environmental students, or to train them by supervising their research projects.

Disciplinary envy and competition, and turf wars, can still show themselves of course. The OEP has weathered several such events, when other academic units have wanted to dilute the cross-university model. To some extent these matters are mitigated through the AAC and the stream coordinators who ensure that there is a forum in which to raise, discuss and resolve Faculty- or discipline-specific issues such as changes in stream enrolments, staffing gaps, and curriculum. They also report on structural changes within the Faculties where possible, insuring a better flow of information. A general point is that where inter-Faculty competition and distrust of interdisciplinary exists, alternative programs like the OEP have to talk the language of fees and finance to disciplinarians and to Deans and Heads of Departments. There is no way around this, since excellence in teaching costs money. ${ }^{9}$

In the case of the OEP, there was one specific innovation that has endured. Students are charged not for a whole Masters course, but for the individual classes they take. Finance managers sometimes find this difficult and this is very uncommon in higher education, because there is little certainty of obtaining the whole year's fees from a student up-front, and this makes financial modeling more difficult. Most Masters across the world charge

\footnotetext{
${ }^{8}$ http://environment.unimelb.edu.au/study/graduate-stories

${ }^{9}$ It is notable that other environmental entities have not survived. We cannot offer our view on these decisions, but the Melbourne School of Land and Environment was dis-established in 2014, and the Batchelor of Environments, a key pathway into the Master of Environment was suspended in 2017.
} 
a fee for a whole course. It took strenuous campaigning in the early 2010 s to retain the charge by class model, which currently sits at around $€ 2,000-€ 2,600$ per class. It simply went against the wishes of finance managers, and it was necessary for the OEP Boards and Director to defend this model very strongly. The reason it is needed is because individual class fees can be allocated to the different parties involved in the teaching program. Students also have some discretion over their fee costs, the speed at which they complete the program, and where and how they assemble their unique degree options.

The model is this. A student enrolls in the OEP Master of Environment. If studying fulltime, they pay for the 4 classes they take each semester (after a small delay to insure they are happy with these classes). Around $80-90 \%$ of the fees go to the Faculty offering the class. ${ }^{10}$ The rest is retained to cover the costs and overheads to run the OEP office. So, if a student takes most of their classes in the particular Faculty, that Faculty becomes a major beneficiary of their interdisciplinary degree. If a Faculty runs no environmental classes, or teaches them poorly and receives few students, they get little to no fee income. By way of example, in 2012 when the first author was last involved, the Melbourne School of Land and Environment (which was science-based but had some environmental social scientists) emerged as a major beneficiary of the OEP, as did the Faculties of Science, Engineering, and to a less extent Business and Economics, and Medicine, Dentistry and Health Sciences. Surplus fee income is ploughed back to the University. The OEP itself makes no profit.

In one fell stroke, using this fee-sharing model, inter-Faculty participation in a cooperative enterprise is encouraged, not discouraged. This is a minor, but significant attack on intra-university competition, which has accompanied the requirements of a neoliberal higher education funding model, and it offers mutual financial and pedagogical benefits borne from cooperation. Faculties are of course free to propose their own, usually more focused, Masters degrees like Environmental Engineering or Urban Planning, where they teach all the students and capture most of the fee revenues themselves. But their participation in an inter-university initiative is a win-win. In 2011, the university recognized this and a series of meetings were held to explore five more programs like the OEP, although to our knowledge most did not advance in the interdisciplinary way envisaged. Perhaps by this point in time, the Faculty fee revenue strongholds were too well established.

\section{Discussion and conclusion}

The OEP is an interesting model for postgraduate environmental education. It had a mission from the outset to be a cross-Faculty initiative, supported by university Faculties but maintaining its own governance structure and identity. It had to overcome several challenges that emanate from the internal structure and governance culture of the University, but also from the financial climate and the neoliberal agenda at play in Australia. After nineteen years of operations it has become remarkably successful by any measure, student enrolment, satisfaction and positive outcomes, and financial sustainability. Conventional indicators of program success, like growth in student numbers, were met along the way to satisfy university and Faculty goals, largely through

${ }^{10}$ Historic data. The percentage is occasionally re-negotiated. 
expanding enrolment and thus financial returns to key university stakeholders. Maintaining a small cohort of students was never possible. Alongside this, the program has been able to pursue goals that are arguably more radical and certainly more transdisciplinary than those of the Faculties and the academic Departments that support it. Many of its students become true interdisciplinary and sustainability professionals and advocates, with a refined sense of environmental and social justice.

There are lessons here for cognate programs in other universities, in the light of sustained demand for courses and skills in the interdisciplinary environmental area. Firstly, cross Faculty, transdisciplinary environmental programs work. They are not the norm, and university managers can find them problematic for a variety of reasons. They are hard to compartmentalize, quite hard to control, and the funding model takes time to understand, to adapt to an institution, and to bed down. They are very rare.

Secondly, to succeed they must be real educational enterprises- not hastily prepared Masters designed to raise revenues. One way to fight the neoliberal model of university management is to remain focused on pedagogy, students, and the transformational potential that programs like this can offer (Apple, 2013; Freire, 1973, 1985). Responsiveness and good communication skills are needed, given the fast-changing and often discipline-focused context in which they operate.

Thirdly, where good communication with Faculty and students and pastoral care is lacking -and at elite universities heavily dedicated to research, this is a persistent problem- it has to be created, in this case outside the Faculty structure. The OEP staff have always included academics dedicated to their students, and an unusual level of individual pastoral care that, historically, was quite unique to this Program, to the best of our knowledge.

Fourthly, the locus of choice, and therefore power, must rest with the individuals participating in the program, recognizing their wide range of interests. From initial recruitment through to graduation, the focus cannot be on whether a Master's program is right for the student, but rather, how it can add to their individual skills and knowledge. How can it enhance their contribution to a field of endeavor that requires commitment and dedication? Thus, while the numerous graduating Masters of the Environment all receive the same degree award from the University of Melbourne, almost every degree they receive has different components. This is a matter of social justice; the program is a vehicle molded to, and by, the student. She or he is entitled to deviate from a pre-existing Masters curriculum. This is empowering, but of course, it can be disconcerting because it offers such a large degree of choice. As educators, we see this choice as liberating rather than disabling, it is a "more meaningful type of pluralism that supports ecological justice and engages with constructive sustainability frameworks" (Kopnina, 2015, p. 126). Globally, hardly any universities run Masters courses in this way, perhaps because they are not aware of the possibilities, or because they have not been able to make others aware and enthusiastic in their organizations.

To conclude, we have argued that is possible to envision and deliver environmental education differently to the vast majority of taught Masters programs, with echoes back to the environmental movements and ideas of earlier decades. Programs like the Master of Environment, a communal effort by academics and staff, are making a difference. They are a small part in a broader sustainability transition. While they have to talk the language of the neoliberal university (student numbers and impact), they are an alternative space 
where personal, institutional and environmental challenges are being met. This is exciting, and challenging. Such programs need agile administration, and a strong environmental, as well as a pedagogical commitment.

\section{Acknowledgements}

We thank past and present staff, students and Board members associated with the Master of Environment degree at the University of Melbourne and the Office for Environmental Programs. Two referees, and Prof. Mark Burgman, provided helpful insights. The article offers personal, not institutional views.

\section{References}

Adams R., Martin, S. and Boom, K. (2018). University culture and sustainability: Designing and implementing an enabling framework. Journal of Cleaner Production, 171, 434-445. https://doi.org/10.1016/j.jclepro.2017.10.032

Apple, M. (2013). Can education change society? New York, NY: Routledge.

Baer, H. A. and Gallois, A. (2018). How committed are Australian universities to environmental sustainability? A perspective on and from the University of Melbourne. Critical Sociology, 44(2), 357-373. https://doi.org/10.1177/0896920516680857

Batterbury, S. P. J. (2008). Tenure or permanent contracts in North American higher education? A critical assessment. Policy Futures in Education, 6(3), 286-297. https://doi.org/10.2304/pfie.2008.6.3.286

Batterbury, S. P. J. and Byrne, J. (2017). Australia: Reclaiming the public university? Social Epistemology Review and Reply Collective, 2, 23-33.

Biggs, J. and Davis, R. (Eds.). (2002). The subversion of Australian universities. Wollongong, NSW: Fund for Intellectual Dissent.

Dlouhá J. and Dlouhý, J. (2014). Higher education for sustainability. A change of education genre? Envigogika, 9(1), 1-31. https://doi.org/10.14712/18023061.440

Emmelin, L. (1977). Environmental education at university level. Ambio, 6(4), 201-209.

Fien, J., Scott, W. A. H. and Tilbury, D. (2001). Education and conservation: Lessons from an evaluation. Environmental Education Research, 7(4), 379-395. https://doi.org/10.1080/13504620120081269

Filho, W. L., Brandli, L. L., Castro, P. and Newman, J. (Eds.) (2017). Handbook of theory and practice of sustainable development in higher education. Dordrecht: Springer.

Freire, P. (1973). Education for critical consciousness. New York, NY: Seabury Press.

Freire, P. (1985). The politics of education: Culture, power and liberation. South Hadley, MA: Bergin and Garvey Publishers. https://doi.org/10.1007/978-1-349-17771-4

Hanover Research Council. (2009). Environmental studies program demand. Retrieved from http://www.niu.edu/envs/resources/Environmental\%20Studies\%20Program\%20Deman d.pdf

Jickling R. and Sterling, S. (Eds.). (2017). Post-sustainability and environmental education: Remaking education for the future. Plymouth: Palgrave Macmillan. https://doi.org/10.1007/978-3319-51322-5 
Kopnina, H. (Ed.). (2012). Anthropology of environmental education. Long Island, NY: Nova Science.

Kopnina, H. (2015). Neoliberalism, pluralism and environmental education: The call for radical reorientation. Environmental Development, 15, 120-130. https://doi.org/10.1016/j.envdev.2015.03.005

Kull, C. A. and Batterbury, S. P. J. (2017). L'environnement dans les géographies anglophone et française: émergence, transformations et circulations de la political ecology. In G. Blanc, E. Demeulenaere and W. Feuerhahn (Eds.), Humanités environnementales: enquêtes et contreenquêtes (pp. 117-138). Paris: Publications de la Sorbonne.

Monroe M. C., Andrews, E. and Biedenweg, K. (2008). A framework for environmental education strategies. Applied Environmental Education and Communication, 6(4), 205-216. https://doi.org/10.1080/15330150801944416

Noy, S., Patrick, R., Capetola, T. and McBurnie, J. (2017). Inspiration from the classroom: A mixed method case study of interdisciplinary sustainability learning in higher education. Australian Journal of Environmental Education, 33(2), 97-118. https://doi.org/10.1017/aee.2017.22

Palmer, J. (2002). Environmental education in the 21st century: Theory, practice, progress and promise. London: Routledge.

Shmelev, S. (Ed.). (2017). Green economy reader: Lectures in ecological economics and sustainability. Dordrecht: Springer. https://doi.org/10.1007/978-3-319-38919-6

Soule, M. E. and Press, D. (1998). What is environmental studies? BioScience, 48(5), 397-405. https://doi.org/10.2307/1313379

Times Higher Education. (2017). World university rankings, University of Melbourne. Retrieved from https://www.timeshighereducation.com/world-university-rankings/universitymelbourne

University of Melbourne. (2016). Sustainability charter. Retrieved from http://sustainablecampus.unimelb.edu.au/about-us/strategy/sustainabilitycharter/charter

University of Melbourne. (2017). Sustainability plan 2017-2020. Retrieved from https://ourcampus.unimelb.edu.au/application/files/2914/8480/0942/UoM_Sustainabili ty_Plan_2017-2020_40pp.pdf

Wilson, G. (2012). The lived experience of climate change: Expanding the knowledge base through collaborative master's curriculum in the European Union. International Journal of Innovation and Sustainable Development, 6(1), 43-52. https://doi.org/10.1504/IJISD.2012.046052

Winter, J. and Cotton, D. (2012). Making the hidden curriculum visible: Sustainability literacy in higher education. Environmental Education Research, 18(6), 783-796. https://doi.org/10.1080/13504622.2012.670207 


\section{Brief CV of the authors}

\section{Simon P. J. Batterbury}

Professor of Political Ecology, Lancaster University, UK and Principal Research Fellow, Geography, University of Melbourne, Australia. Director of the Office of Environmental Programs at the University of Melbourne, 2008-2012, and editor of the open access Journal of Political Ecology since 2003. He has conducted research on rural development and agrarian change in Burkina Faso, Niger, and East Timor since 1992, and currently on the impacts of mining for Indigenous communities in New Caledonia. Publications and further information: www.simonbatterbury.net. ORCID ID: 0000-0002-2801-7483. Email: simonpjb@unimelb.edu.au

\section{Maurizio Toscano}

Lecturer in the Graduate School of Education at the University of Melbourne. He is an academic research and teaching work focuses on understanding the relationships between science, art, the environment, philosophy and education. His work is informed by these wide-ranging academic experiences: his doctoral training was in astrophysics. He has undertaken and supervised research into aesthetics and the scientific imagination; he has produced artworks, collaborated with artists and written about art and science; and more recently he has examined philosophical perspectives on science and education that draw upon the works of Heidegger, Cavell, Nietzsche and Sloterdijk. ORCID ID: 0000-00018585-0343. Email:m.toscano@unimelb.edu.au 